\title{
Physical and Chemical Properties of Fibrous Residues of Castor Bean Culture
}

\author{
Juliano Souza Vasconcelos ${ }^{1}$, Diego Henrique de Almeida ${ }^{2}$, Tiago Hendrigo de Almeida ${ }^{3}$, \\ Julio Cezar Souza Vasconcelos ${ }^{4}$, André Luis Christoforo ${ }^{1, *}$, José Cláudio Caraschi ${ }^{3}$, \\ Francisco Antonio Rocco Lahr ${ }^{2}$ \\ ${ }^{1}$ Civil Engineering Department, Federal University of São Carlos, São Carlos, 13565-905, Brazil \\ ${ }^{2}$ Structural Engineering Department, Engineering School of São Carlos (EESC/USP), São Carlos, 13566-590, Brazil \\ ${ }^{3}$ Wood Engineering Department, Paulista State University, Campus of Itapeva, Itapeva, 18409-010, Brazil \\ ${ }^{4}$ Mathematics Department, Federal University of São Carlos, São Carlos, 13565-905, Brazil
}

\begin{abstract}
Researches regarding the use of agricultural residues as raw material for the fibrous pulp and paper industries are important, especially the use of castor (Ricinus communis L.), whose application can be found in many sectors of the economy, with its main product derived from the oil of its seeds. Thus, this study aimed to investigate the physico-chemical properties of castor fibrous waste, such as leaves, branches and stems to evaluate the potential of these residues for pulp and paper production. Results of physico-chemical analysis of castor residues revealed the following contents: $80.10 \%$ of holocellulose (50.56\% of cellulose and $29.64 \%$ of hemicellulose); $17.34 \%$ of lignin; $1.48 \%$ of ash; $1.24 \%$ of extractives soluble in hot water; and $1.88 \%$ of extractives soluble in organic solvents. In general, fibrous crop residues of castor presented as a good alternative for pulp and paper manufacturing, since they have high cellulose content compared with its basic density.
\end{abstract}

Keywords Residues, Castor bean culture, Holocellulose content, Cellulose content

\section{Introduction}

Searching for new materials around the world is very important to meet human needs. Castor bean (Ricinus communis L.) is an oilseed plant found in many regions of Brazil, with great social importance, can be cultivated by small agricultural producers [1].

Application of castor can be performed in numerous sectors of the economy, with its main product derived oil from its seeds [2]. Castor oil is used in the manufacture of paints, lubricants, cosmetics, other pharmaceutical drugs and also as adhesives in wood-based panels and lignocellulosic materials [3-5].

Brazilian pulp and paper industries present crescent demand, getting a large growth in recent decades. The successful use of fibrous raw materials of appropriate from good silvicultural treatments and better industrial processes contributed to the success of these segments [6].

To meet the needs of the sector related to obtaining raw materials, using wood from planted forests (mainly genera

* Corresponding author:

alchristoforo@yahoo.com.br (André Luis Christoforo)

Published online at http://journal.sapub.org/ijme

Copyright (C) 2014 Scientific \& Academic Publishing. All Rights Reserved
Eucalyptus and Corymbia) is the most widely practice $[7,8]$.

Researches regarding the use of agricultural residues as feedstock for the fibrous pulp and paper are important. Studies with crop residue of cane sugar [9] and banana [10] showed satisfactory results and which allow the use of these residues in paper industry.

Research with three different crops of castor beans shows ram that fibers from plant stem, compared with Pinus and Eucalyptus fibers (main genera in Brazilian planted forests) are considered, respectively, as long and short [11].

Technological characteristics of castor beans present it as a possible raw material for of pulp and paper production, however, we must highlight the negative effect of marrow stem that is not a fibrous material, what do can negatively affect the pulp yield and paper [12].

In addition to the products and by-products of castor bean plantation, a large amount of fibrous agricultural residues are produced. Production waste castor (leaves, branches and stems) are often burned in order to prepare the soil for next planting $[11,12]$.

In this context, the aim of this paper consists in to determine physico-chemical properties of fibrous waste castor beans, such as leaves, branches and stems to evaluate the potential of these residues for pulp and paper. 


\section{Material and Methods}

Castor crop residues (stems, branches and leaves of plants) from plantations in the state of São Paulo were used. After dried, they were processed in the mill type grinder. Sawdust produced was classified as sieves to obtain the fraction between 40/60 mesh, as recommended by Code T $264 \mathrm{CM}$ : 2007 [13].

\section{- Analysis of physical properties}

\section{- Determination of moisture content of castor}

Determination of moisture content of castor was performed according to the Brazilian standard ABNT NBR 1986 [14]. In a pre-weighed filter, $1 \mathrm{~g}$ of sample was added, taken to the oven $\left(105 \pm 2^{\circ} \mathrm{C}\right)$ for about 4 hours and, then, transferred into the weigh-filters to a desiccator until constant weight. Moisture content of castor oil was given by Equation 1:

$$
\% \text { Moisture }=\frac{m_{1}-m_{2}}{m_{1}} \cdot 100
$$

where: $\%$ Moisture $=$ castor moisture $(\%) ; m_{1}=$ mass of wet sample $(\mathrm{g}) ; m_{2}=$ mass of dry sample $(\mathrm{g})$.

\section{- Determination of bulk density of castor:}

Bulk density was determined according to Code SCAN-CM 46:1992 [15]. Procedure consisted of determining the mass of the sample in a known volume bottle, and was repeated several times for each sample until obtaining five measurements with an average deviation lower than $5 \%$.

Bulk density is he ratio between the fibers mass and volume occupied by them, Equation 2:

$$
d=\frac{m}{V}
$$

where: $d=$ apparent density $\left(\mathrm{g} / \mathrm{cm}^{3}\right) ; m=$ mass of dry sample castor $(\mathrm{g}) ; V=$ volume of dry sample castor $\left(\mathrm{cm}^{3}\right)$.

\section{- Determination of castor density:}

Determination of density of the castor was performed according to standard ABTCP: 1974 [16].

The chips were positioned in a plastic net and placed in a box with water until complete saturation. So, chips immersed in water were weighed in a hydrostatic balance, $10 \mathrm{mg}$ precision. After removing superficial water from the chips, they were weighed on the same balance. Then, the chips were dried $\left(105 \pm 2^{\circ} \mathrm{C}\right)$, cooled in a desiccator and weighed again. Specific gravity was determined using Equation 3:

$$
d_{b}=\frac{m s}{m v-m i}
$$

where: $d_{b}=$ basics density $\left(\mathrm{g} / \mathrm{cm}^{3}\right) ; m s=$ mass of dry sample in oven $(\mathrm{g}) ; m v=$ mass of saturated sample with water $(\mathrm{g}) ; m i$ $=$ mass of saturated timber immersed in water $(\mathrm{g})$.

\section{- Analysis of the chemical properties}

\section{- Holocellulose content in castor:}

In a flask with $250 \mathrm{~mL}$ was added $4 \mathrm{~g}$ of dry sample of ground castor and classified in sieves 40 and 60 mesh, 140 $\mathrm{mL}$ of distilled water, $3 \mathrm{~mL}$ of glacial acetic acid, $3.3 \mathrm{~g}$ of sodium chlorite and $43 \mathrm{~g}$ of sodium acetate. The flask was capped with another conical flask of $25 \mathrm{ml}$ inverted on the first and the assembly was placed in a thermostat at $70 \pm 2^{\circ} \mathrm{C}$.

The reaction mixture was kept under stirring and after 30 minutes were added $3.0 \mathrm{~mL}$ of glacial acetic acid and $3.3 \mathrm{~g}$ of sodium chlorite. This treatment was repeated four more times. At the end of 150 minutes the mixture was cooled below $10^{\circ} \mathrm{C}$ and then filtered on a sintered glass funnel tared. Holocellulose (solid residue) was washed with about $1 \mathrm{~L}$ of distilled water until the filtrate or exit colorless and neutral $\mathrm{pH}$. It was then washed three times with ethanol and dried at $105 \pm 5^{\circ} \mathrm{C}$. Cooled down in a desiccator until constant weight. The percentage of holocellulose was obtained from Equation 4:

$$
\% \text { Holocellulo se }=\frac{m_{H}}{m_{A}} \times 100
$$

where: \%Hollocelulose $=$ holocellulose content in castor $(\%)$; $m_{H}=$ dry weight of holocellulose $(\mathrm{g}) ; m_{A}=$ free sample mass of extractives and moisture $(\mathrm{g})$.

\section{- Cellulose content in castor:}

In a beaker with $100 \mathrm{~mL}$ was placed $1 \mathrm{~g}$ of holocellulose and $15 \mathrm{ml}$ of potassium hydroxide. After 15 hours under stirring, filter the mixture into a sintered glass funnel $\mathrm{n} .1$ tared, washing the precipitate with distilled water to neutral, then washed with $1 \%$ acetic acid and finally with excess ethanol. The pulp obtained was dried in ambient air for 48 hours at $105 \pm 5^{\circ} \mathrm{C}$ for 30 minutes. Cooled down to pulp in a desiccator to constant weight. It was determined the content of cellulose from Equation 5:

$$
\% \text { Cellulose }=\frac{m_{C}}{m_{H}} \times 100
$$

where: $\%$ Cellulose $=$ cellulose content in castor $(\%) ; m_{C}=$ mass of dry cellulose (g).

\section{- Hemicellulose content in castor:}

The hemicellulose content was determined by the difference between the content of holocellulose and cellulose, according to Equation 6:

$$
\% \text { Hemicellulose }=\% \text { Holocelulose }-\% \text { Celulose }
$$

where: $\%$ Hemicellulose $=$ hemicellulose content of the castor (\%);

\section{- Lignin content in castor:}

The determination of the percentage of lignin was performed in duplicate for samples of castor. The methods are specified in standard T 222 OM [17]. 


\section{- Content of extractives soluble in hot water in castor:}

Was added to about $10.0 \mathrm{~g}$ material in a container with 500 $\mathrm{ml}$ distilled water. The mixture was heated at reflux temperature for 4 hours then filtered and the dried material. It was determined the percentage of extractives soluble in hot water by the difference in mass of dry feedstock before and after the extraction process, according to Equation 7:

$$
\% \text { Extractives }_{1}=\frac{m_{k}-m_{b}}{m_{k}} \times 100
$$

where: $\%$ Extractives $_{1}=$ percentage of extractives soluble in hot water $(\%) ; m_{k 1}=$ mass of dry material not extracted with hot water $(\mathrm{g}) ; m_{b}=$ mass of dry material extracted with hot water $(\mathrm{g})$.

\section{- Content of extractives soluble in organic solvents in castor:}

The residue samples castor experienced a process of extraction in a Soxhlet extractor using a mixture of cyclohexane/ethanol at a ratio one to one volume over a period of 8 hours in order to remove the organic-soluble extractives. After extraction, the sample was dried in air and then in an oven with air circulation at $105 \pm 5^{\circ} \mathrm{C}$ for 24 hours. It was determined the percentage of extractives on the difference in mass of dry feedstock before and after the extraction process according to Equation 8:

$$
\% \text { Extractives }_{2}=\frac{m_{k 1}-m_{b 1}}{m_{k 1}} \times 100
$$

where: $\%$ Extractives $_{2}=$ percentage of extractives soluble in organic solvents $(\%) ; m_{k l}=$ mass of dry material not extracted with organic solvents $(\mathrm{g}) ; m_{b 1}=$ mass of dry material extracted with organic solvents $(\mathrm{g})$.

\section{- Ash content in castor:}

For the determination of inorganic material (ash), used pre-weighed crucibles up to $600^{\circ} \mathrm{C}$. $1 \mathrm{~g}$ of sample were placed in the crucible. Following is externally heated crucibles in a Bunsen burner, promoting the slow combustion of the sample, until no more calls inside. It took the crucibles in muffle furnace $\left(600^{\circ} \mathrm{C}\right)$ for 4 hours. The calcined samples were placed in a desiccator for cooling to constant weight. The ash content was determined by the Equation 9:

$$
\% A s h=\frac{m_{3}}{m_{2}} \times 100
$$

where: $\% A s h=$ ash percentage in castor $(\%) ; m_{3}=$ mass of ash (g).

\section{Results and Discussions}

Table 1 shows the results for the physical properties of the waste castor.

The values determined for the physical properties were close to the values determined by other researchers for castor. The basic density of castor oil is lower than the density of the woods Eucalyptus [18].

Table 1. Physical properties of castor bean waste

\begin{tabular}{cc}
\hline$\%$ Moisture $(\%)$ & 10.19 \\
\hline $\mathrm{d}\left(\mathrm{g} / \mathrm{cm}^{3}\right)$ & 0.35 \\
\hline $\mathrm{d}_{\mathrm{b}}\left(\mathrm{g} / \mathrm{cm}^{3}\right)$ & 0.28 \\
\hline
\end{tabular}

Table 2 shows the results for the chemical analysis of residues of castor oil.

Table 2. Chemical analysis of residues of castor

\begin{tabular}{cc}
\hline$\%$ Hollocelulose (\%) & 80.10 \\
\hline$\%$ Celullose (\%) & 50.46 \\
\hline$\%$ Hemicellulose (\%) & 29.64 \\
\hline$\%$ Lignin (\%) & 17.34 \\
\hline$\%$ Ash (\%) & 1.48 \\
\hline$\%$ Extractives $_{1}$ & 1.24 \\
\hline$\%$ Extractives $_{2}$ & 1.88 \\
\hline
\end{tabular}

The sum of the chemical constituents in the chemical analysis shows a percentage equal to $102.4 \%$, and this is acceptable, due to the large number of individual analysis can overlap combined with the addition of individual errors in the interpretation of results [19] results.

The residues of castor analyzed in this study showed an interesting amount of cellulose (more than 50\% of the chemical composition) and few undesirable constituents such as ash and extractives. The holocellulose content was very close to those found in the woods of the genus Eucalyptus.

Compared with Eucalyptus woods, fibrous crop residues of castor have less lignin content [18].

The ash content of samples varies from Eucalyptus species and location of the plant, ranging from $0.5 \%$ to $5 \%$ [18]. The lignin content of castor analyzed in this study was around $1.5 \%$.

\section{Conclusions}

Fibrous crop residues of castor presented as a good alternative to the pulp and paper industries therefore have high cellulose content compared with the basic density.

\section{ACKNOWLEDGMENTS}

The authors thank the UNESP Campus of Itapeva, Laboratory of Pulp and Paper, the possibility of this research. We also thank CAPES and CNPq for financial support. 


\section{REFERENCES}

[1] Ventura, D. A. M. F.; Alves, K. B.; Santos, M. K. V. A. Análise comparativa entre o biodiesel de girassol e biodisesel de mamona. In: CONGRESSO BRASILEIRO DE MAMONA, 4, João Pessoa, 2010. Proceedings... João Pessoa: EMBRAPA, 2010. CD-ROM.

[2] Naka, S. Determinação das propriedades físicas dos grãos de mamona "Guarani" visando armazenagem em silos verticais. Dissertação de Mestrado. Faculdade de Engenharia Agrícola, Universidade Estadual de Campinas, Campinas, 2010.

[3] Goneli, A. L. D. Variação das propriedades físico-mecânicas e de qualidade da mamona (Ricinus communis L.) durante a secagem e o armazenamento. Tese de Doutorado. Universidade Federal de Viçosa, Viçosa, 2008.

[4] Silva, S. A. M.; Christoforo, A. L.; Panzera, T. H.; Almeida, D. H.; Segantini, A. A. S.; Lahr, F. A. R. Painéis de partículas de madeira leucena e resina poliuretana derivada de óleo de mamona, Ciência Rural, v.43, n.8, p. 1399-1404, 2013.

[5] Ferro, F. S. Painéis OSB com madeira Schizolobium amazonicum e resina poliuretana à base de óleo de mamona. Dissertação de Mestrado. Escola de Engenharia de São Carlos, Universidade de São Paulo, São Carlos, 2013.

[6] Georg, I. C. Modelagem e simulação da polpação kraft antraquinona. Dissertação de Mestrado. Universidade Federal de Santa Catarina, Florianópolis, 2000.

[7] Silva, D. J.; Gomide, J. L.; Colodette, J. L. Utilização de surfactantes, na polpação kraft de madeira de Eucalipto, como auxiliar na remoção de extrativos lipofílicos, Revista Árvore, v. 28, n.6, p. 911-917, 2004.

[8] Gouvêa, A. F. G.; Trugilo, P. F.; Colodette, J. L.; Lima, J. T.; Silva, J. R. M.; Gomide, J. L. Avaliação da madeira e da polpação kraft em clones de Eucalipto, Revista Árvore, v. 33, n.6, p. 1175-1185, 2009.

[9] Rossi, F. G. Análise dos processos de polpação do bagaço de cana-de-açúcar: estudo termocinético da influência da antraquinona no tratamento alcalino. Tese de Doutorado. Faculdade de Engenharia Química, Universidade Estadual de Campinas, Campinas, 2012.

[10] Soffner, M. L. A. P. Produção de polpa celulósica a partir de engaço de bananeira. Dissertação de Mestrado. Escola Superior de Agricultura "Luiz de Queiroz", Universidade de São Paulo, Piracicaba, 2001.

[11] Azzini, A.; Salgado, A. L. B.; Savy Filho, A.; Banzatto, N. V. Restos vegetais da cultura da mamona como matéria-prima para celulose, Revista Bragantia, v. 40, p. 1-10, 1981.

[12] Azzini, A.; Savy Filho, A.; Salgado, A. L. B.; Arnaldi, F. Z. Desliginificação dos resíduos agrícolas da cultura da mamona para produção de celulose e papel, Revista Bragantia, v. 43, n. 2, p. 519-530, 1984

[13] Technical Association of the Pulp and Paper Industry (TAPPI). T 264 CM: Preparation of wood for chemical analysis. Peachtree Corners, 2007.

[14] Associação Brasileira de Normas Técnicas (ABNT). NBR 9533: Determinação de umidade por secagem em estufa. Rio de Janeiro, 1986.

[15] Scandinavian Pulp, Paper and Board. SCAN-CM 46: Bulk density. Stockholm, 1992.

[16] Associação Brasileira Técnica de Celulose e Papel (ABTCP). ABTCP: Métodos de ensaio. São Paulo, 1974.

[17] Technical Association of the Pulp and Paper Industry (TAPPI). T 222 OM: Acid-insoluble lignin in wood and pulp. Peachtree Corners, 2002.

[18] Pereira, J. C. D.; Sturion, J. A.; Higa, R. C. V.; Shimizu, J. Y. Características da madeira de algumas espécies de Eucalipto plantadas no Brasil. Colombo: EMBRAPA, 2000. 113 p.

[19] Klock, U.; Muñiz, G. I. B.; Hernandez, J. A.; Andrade, A. S. Química da madeira. Curitiba: UFPR, 2005. 85 p. 